\title{
THE CODE OF MUSLIM PERSONAL LAWS OF THE PHILIPPINES: BEYOND THE LENSES OF BONDAGJY v. BONDAGJY*
}

\author{
Norhabib Bin Suod Sumndad Barodi**
}

\begin{abstract}
The dynamics of mixed marriages governed by the Code of Muslim Personal Laws of the Philippines (Muslim Code) creates variables that sometimes lead to the non-application of the said Code to Shari'ah cases arising from said marriages. This is highlighted in the familiar but controversial case of Bondagjy v. Bondagjy, wherein the Supreme Court of the Philippines did not apply the Muslim Code on the issue of custody of minor children born to a Muslim marriage prior to becoming 'mixed' by the conversion of the female party (Muslim convert) to another religion. The article argues that whatever variables are attendant in a specific conflict of rights where the Muslim Code applies, the resolution of said conflict must be in accordance with its provisions or other applicable Muslim laws. This perspective sustains the character of the Muslim Code as the applicable law in each Shari' $a$ h case and disfavours the diminution of said character by the non-application of the Muslim Code. The article further argues that the application of the provisions of the Muslim Code affecting conflict of rights must be reinforced with the requisite good faith and honesty on the part of each party, Muslim and non-Muslim alike, to ensure a just and fair resolution of each Shari' $a$ h case. The article achieves its gist by evaluating how the 'applicability clause', the 'construction and interpretation rules', and the 'conflict of provisions rules' of the Muslim Code operate in the context of and beyond Bondagjy v. Bondagjy and other relevant cases. This critical analysis highlights the present status of the Muslim Code as the initial premise in the formulation of measures that are responsive to and promotive of the role of mixed marriage as a
\end{abstract}

\footnotetext{
* This article was delivered by the author as an abbreviated paper presentation during the University of the Philippines, Institute of Islamic Studies (UP IIS) 1 st International Conference and Workshop held on Sept. 21-22, 2018.

** Associate Professor, Mindanao State University College of Law. Email: nbs.barodi@gmail.com.
} 
significant avenue for Muslim and non-Muslim relations in the Philippines and other foreign jurisdictions where similar relations exist.

Keywords: Muslim Code, mixed marriage, good faith and honesty, custody

\title{
KOD UNDANG-UNDANG PERIBADI MUSLIM DI FILIPINA: DI LUAR KANTA BONDAGJY v. BONDAGJY
}

\begin{abstract}
ABSTRAK
Perkahwinan campuran di antara penganut Islam dan Kristian di Filipina ditadbir oleh Kod Undang-Undang Peribadi Muslim (Kod Muslim) dimana amalan ini mengakibatkan pembolehubah yang menyebabkan ketidak pakaian Kod pada kes-kes Syari'ah. Perkara ini telah diserlahkan di dalam kes Bondagjy mlwn. Bondagjy yang kontroversi di mana Mahkamah Tertinggi (Supreme Court) Filipina telah memilih untuk tidak menggunakan Kod Muslim dalam menentukan hak jagaan anak-anak bawah umur yang dilahirkan di dalam perkahwinan Islam sebelum menjadi "perkahwinan campur" akibat dari penukaran agama oleh pihak perempuan (Muslim) kepada agama lain. Makalah ini menghujahkan bahawa tanpa mengira apa-apa pembolehubah yang terlibat dalam konflik berkenaan perkahwinan campuran, hak-hak Muslimin yang terkandung dalam Kod Muslim kekal terpakai atau resolusi kepada konflik tersebut mestilah mematuhi peruntukan Kod Muslim atau undang-undang Muslim yang terpakai. Perspektif ini mengekalkan watak Kod Muslim sebagai undang-undang yang di guna pakai didalam semua kes Shari'ah dan menidakkan pengurangan usaha menidakkan pemakaian Kod Muslim. Makalah ini seterusnya menghujahkan bahawa pemakaian peruntukan Kod Muslim yang melibatkan konflik berkaitan hak-hak kedua-dua belah pihak mestilah dikuatkuasakan dengan suci hati dan jujur oleh kedua-dua pihak Muslim dan bukan Muslim. Ini bagi memastikan resolusi yang adil dan saksama bagi setiap kes Shari'ah. Makalah ini menilai bagaimana 'klausa kebolehgunaan', 'peraturan pembinaan dan tafsiran' dan 'peraturan konflik dalam provisi' bagi menangani masalah pemakaian Kod Muslim dalam konteks kes Bondagjy mlwn Bondagjy dan kes-kes lain yang releven. Analisa kritikal ini menyorot status terkini Kod Muslim ke atas premis awal dalam memformulasi langkah-langkah responsif dan promotif bagi mengawal selia perkahwinan campur dan memberikan peluang untuk
\end{abstract}


pemulihan perhubungan antara Muslim dan non-Muslim di Filipina dan bidang kuasa asing di mana perhubungan seperti ini ujud.

Katakunci: Kod Muslim, perkahwinan campur, niat baik dan kejujuran, hak penjagaan

\section{INTRODUCTION}

The codification of Muslim personal laws, into what is now referred to as the Code of Muslim Personal Laws of the Philippines ${ }^{1}$ (Muslim Code for brevity), brought to realization the enforcement of this system of personal laws for the benefit of the Muslims in the Philippines. It embodies, among others, the pertinent rules governing the Islamic institutions of marriage and family. In Islam, marriage is a sacred social institution tracing its sanctity to the Holy Qur'an and Sunnah no less. Accordingly, the Muslim Code reflects a system that ensures the cohesive nature of marriage as a social institution. This system consists of substantive provisions that, if put into faithful practice by the spouses, would bring stability and happiness to their marriage. For instance, the Muslim Code provides for the exclusive and mutual rights and obligations of the husband and wife. A recognition and respect of these rights by both parties to the marriage is vital to a happy marital and family life. However, it is inevitable that conflicts of rights sometimes arise between the husband and wife. In this respect, the Muslim Code becomes the measure by which conflicts of rights under its provisions are resolved.

Furthermore, though the preservation of marital ties is of paramount importance, yet there are extraordinary instances where the severance of the marital knot that binds together the husband and wife becomes the most practical and realistic thing to do. The Muslim Code also recognizes this reality through the Islamic concept of divorce (talaq). After marriage dissolution, certain conflicts of rights between the former spouses, e.g. issue of custody over minor children, may likewise arise. Bondagjy $v$. Bondagjy, ${ }^{2}$ the case that caught the attention of Muslim civil and Shari'ah lawyers in the Philippines, exemplifies this.

\footnotetext{
${ }^{1}$ Presidential Decree No. 1083.

${ }^{2}$ Bondagjy v. Bondagjy, G.R. No. 140817, December 7, 2001.
} 
In resolving conflicts of rights between present or former spouses, the first task is to determine if the Muslim Code provisions apply in the first place. There are marriage instances wherein the Muslim Code provisions do not apply even if the parties thereto are Muslims. Conversely, there are marriage instances wherein the Muslim Code applies even if one of the parties is a non-Muslim. Thus, the Muslim Code provides for applicability rules to determine which marriages are governed by the Muslim Code and other applicable Muslim laws. Likewise, in resolving these conflicts of rights, the courts may have to resort to construction and interpretation to arrive at a fair and just resolution of the case. Notably, even the construction and interpretation of the Muslim Code provisions are subject to limitations that said Code also provides, e.g. Article 3(3) 3 thereof.

Initially, the task of resolving these conflicts seems to be uncomplicated, especially if the spouses involved are both Muslims. However, Shari'ah courts may have to consider certain variables that affect how these conflicts of rights are resolved through the applicable Muslim Code provisions. These variables could arise from mixed marriages between Muslim males and non-Muslim females. Relevant thereto is the explicit rule in the Muslim Code that declares, nothing in it shall be construed to operate to the prejudice of a non-Muslim. This behoves a critical analysis at the very least. The nature of the administration of justice requires that there must be a fair and just resolution of every case even if the conflict of rights sought to be resolved is between a Muslim and his non-Muslim spouse. The essence of justice dictates that whatever variables are attendant in a specific conflict of rights, the resolution of the conflict must be fair and just in accordance with law.

The author argues that whatever variables are attendant in a specific conflict of rights where the Muslim Code applies, its resolution must be in accordance with the Muslim Code provisions or other applicable Muslim laws, and not civil law or the Family Code of the Philippines. Consequently, the 'applicability clause', the 'construction and interpretation rules', and the 'conflict of provisions rules' of the Muslim

3 "The provisions of this Code shall be applicable only to Muslims and nothing herein shall be construed to operate to the prejudice of a non-Muslim." 
Code must be sustained so that the character of the Muslim Code as the applicable law in each Shari' ah case is not diminished. This is true even if the Muslim Code collides with other laws, if under the 'conflict of provisions rules' of the Muslim Code the latter must prevail. This article explores this proposition by evaluating how these rules operate in the context of and beyond Bondagjy v. Bondagjy and other pertinent cases. From such a critical analysis, this article highlights how the application, or non-application, of the Muslim Code to a Shari'ah case affects the role of mixed marriage as an avenue for Muslim and non-Muslim relations in the Philippines and other foreign jurisdictions where similar relations exist. By understanding the implications of the Muslim Code's application or non-application to Shari'ah cases arising from mixed marriages, the article establishes the initial premise for responsive and affirmative measures on how 'mixed marriage' as a social institution can serve as a healthy, profound, and significant avenue for constructive and meaningful Muslim and non-Muslim relations not only in the Philippines but also in other jurisdictions where civil law and Muslim personal laws interact.

\section{APPLICABILITY OF THE MUSLIM CODE TO MIXED MARRIAGES UNDER ARTICLE 13(1) AND ARTICLE 186(2)}

The applicability of the Muslim Code clause on marriage and divorce under Article 13 indicates the category of mixed marriages to which the Muslim Code provisions apply. It reads as follows:

Article 13. Application.

(1) The provisions of this Title shall apply to marriage and divorce wherein both parties are Muslims, or wherein only the male party is a Muslim and the marriage is solemnized in accordance with Muslim law or this Code in any part of the Philippines.

(2) In case of marriage between a Muslim and a non-Muslim, solemnized not in accordance with Muslim law or this Code, the Civil Code of the Philippines shall apply...

A reading of Article 13(1) reveals that the Muslim Code applies to marriage and divorce "wherein only the male party is a Muslim and the marriage is solemnized in accordance with Muslim law or this Code in any part of the Philippines.' In other words, for the Muslim Code to govern the mixed marriage referred to in Article 13(1), the male party 
thereto must be a Muslim, the solemnization is in accordance with Muslim law or the Muslim Code, and the solemnization takes place in any part of the Philippines. An illustrative example of mixed marriage that does not fall within the ambit of Article 13(1) is found in the case of Rulona-Al Awadhi v. Astih, ${ }^{4}$ where the Supreme Court of the Philippines held that the Muslim Code does not apply. In this case, the marriage of Jocelyn, though a Filipino citizen but a non-Muslim, and Nabil, a Kuwaiti Muslim, was not solemnized in any part of the Philippines but in Kuwait. Accordingly, the Muslim Code did not apply to their mixed marriage even if the same was solemnized presumably in accordance with Islamic rites in Kuwait. Interestingly, the Rulona-Al Awadhi ruling referred to Nabil Al-Awadhi as 'not a Philippine Muslim but a Kuwaiti national'. This behoves a clarification for this might lead to an interpretation that for the second clause of Article 13(1) to apply, the 'Muslim' referred to therein must be a Philippine Muslim.

The present author believes that the Muslim Code would apply, had the Muslim marriage between Jocelyn and Nabil been solemnized in accordance with Muslim law in any part of the Philippines. In other words, the applicability of Article 13(1) on mixed marriage does not depend on whether the 'Muslim' referred to therein is a Philippine Muslim. Article 13(1) would still apply even if the Muslim male is a foreigner so long as the marriage is solemnized in accordance with Muslim law or the Muslim Code in any part of the Philippines. Thus, the Muslim Code should have been applicable to the marriage of a Filipina and a Saudi Muslim in Bondagjy v. Bondagjy because their marriage was solemnized in accordance with Islamic rites at the Manila Hotel, Ermita, Manila. ${ }^{5}$ This complies with Article 13(1) of the Muslim Code $^{6}$ even if the Muslim husband in the said marriage was not a 'Philippine Muslim' but a Saudi Muslim.

${ }^{4}$ Jocelyn Rulona-Al Awadhi v. Hon. Abdulmajid J. Astih, District Judge of the Fourth Sharia Judicial District Court and Nabil Al-Awadhi, G.R. No. 81969, September 26, 1988.

${ }^{5}$ See Bondagjy v. Bondagjy, G.R. No. 140817, December 7, 2001.

${ }^{6}$ Article 13. Application. (1) The provisions of this Title shall apply to marriage and divorce wherein both parties are Muslims, or wherein only the male party is a Muslim and the marriage is solemnized in accordance with Muslim law 
Interestingly, the Supreme Court of the Philippines in Bondagjy v. Bondagjy applied civil law, and not the Muslim Code, on the issue of custody of the minor children. This article will address this issue later on in a later part of this article.

Mixed marriages between Muslim males and non-Muslim females contracted prior to the enforcement of the Muslim Code may still come under the applicability of the said Code. This is evident from the provisions of Article 186 (2), which reads as follows:

Article 186. Effect of code on past acts.

(2) A marriage contracted by a Muslim male prior to the effectivity of this Code in accordance with non-Muslim law shall be considered as one contracted under Muslim law provided the spouses register their mutual desire to this effect.

Pursuant to this provision, for a mixed marriage between a Muslim male and non-Muslim female contracted prior to the coming into force of the Muslim Code, to come under the operation of its provisions, the spouses shall register their mutual desire to that effect.

Parenthetically, the mixed marriages governed by Article 13(1) and Article 186(2) retain their status as Islamic institutions though they are of a mixed character. Thus, in these mixed marriages, any conflict of rights between the Muslim and the non-Muslim spouses shall be resolved in accordance with the Muslim Code provisions or Muslim law. However, the resolution of Shari'ah cases involving conflict of rights between spouses in mixed marriages shows how several Muslim Code provisions may work to the advantage of the non-Muslim spouse at the expense of sidestepping the applicability of the Muslim Code.

\section{'SAFETY NET' PROVISIONS FOR THE NON-MUSLIM SPOUSE IN MIXED MARRIAGES}

There are several provisions within the Muslim Code that are designed to safeguard the non-Muslim spouse in mixed marriages. Chief among these

or this Code in any part of the Philippines. [Boldfacing and underscoring supplied] 
provisions is Article 3(3), which provides, "The provisions of this Code shall be applicable only to Muslims and nothing herein shall be construed to operate to the prejudice of a non-Muslim." This provision arguably supplies the most effective and comprehensive safeguard in favor of a non-Muslim insofar as the Muslim Code is concerned. It categorically states that the Muslim Code is applicable only to Muslims. Even if to some extent the application of the Muslim Code provisions to a nonMuslim becomes inevitable for the complete resolution of a Shari'ah case, still nothing in the Muslim Code shall be construed to operate to the prejudice of the non-Muslim party.

Article 13(2) likewise provides, "In case of marriage between a Muslim and a non-Muslim, solemnized not in accordance with Muslim law or this Code, the Civil Code of the Philippines shall apply." Hence, if a Muslim male contracts marriage with a non-Muslim female not in accordance with Muslim law or the Muslim Code, the Civil Code of the Philippines shall apply. An illustrative case is Tamano v. Ortiz, ${ }^{7}$ where the Supreme Court of the Philippines held for the Civil Code applicability considering that petitioner Estrellita J. Tamano and the late Senator Tamano were married in accordance with the Civil Code. Consequently, the civil law becomes a legal impediment in the exercise by the Muslim male of certain rights under Muslim law or the Muslim Code.

In this jurisdiction, conversion from one religion to another is a legitimate exercise of one's religious freedom. Thus, it may happen that spouses who are initially non-Muslims will decide to convert to Islam as a couple or as individuals. If this happens, their conversion to Islam either jointly or individually will have profound effects on their marriage. This is exactly the concern of Article 178 of the Muslim Code. The entire provision follows.

Article 178. Effect of conversion to Islam on marriage. The conversion of non-Muslim spouses to Islam shall have the legal effect of ratifying their marriage as if the same had been performed in accordance with the provisions of this Code or Muslim law, provided that there is no legal impediment to the marriage under Muslim law.

${ }^{7}$ Estrellita J. Tamano, v. Hon. Rodolfo A. Ortiz, Presiding Judge, RTC-Br. 89, Quezon City, Haja Putri Zorayda A. Tamano, Adib A. Tamano and the Hon. Court of Appeals, G.R. No. 126603, June 29, 1998. 
A cerebral reading of this provision would show that there is an inherent 'safety net' embedded in its language. The provision deals with the 'conversion of non-Muslim spouses'. Thus, for the provision to have complete application on the effect of conversion to Islam on a marriage, the conversion must be on the part of both spouses. If only one of the non-Muslim spouses converts to Islam, then the provision finds no application. In which case, the marriage is not ratified 'as if the same had been performed in accordance with the provisions of this Code or Muslim law'. This situation is prevalent in many existing non-Muslim marriages in that only one of the spouses converts to Islam. Accordingly, the marriage continues to be governed by the non-Muslim law in accordance with which it was originally solemnized.

Article 177 also deals with conversion but in another context. It provides the regulation of conversion:

No conversion of a minor below the age of eighteen years shall be registered by the District or Circuit Registrar without the written consent or permission of the parents or guardian, except when such minor has been emancipated from paternal authority in accordance with law.

From this provision, non-Muslim parents can restrict, by withholding their consent or permission, the registration of the conversion of their minor child in the registry of marriage, divorce, and conversions.

Finally, the applicability clause of the Muslim Code is embodied in Article 187 authorizes the suppletory application of the Civil Code of the Philippines, the Rules of Court, and other existing laws. The provision reads as follows:

Article 187. Applicability Clause. The Civil Code of the Philippines, the Rules of Court and other existing laws, insofar as they are not inconsistent with the provisions of this Code, shall be applied suppletorily.

The author does not suggest that Article 187 is utterly disadvantageous to the Muslim spouse. In fact, it does not allow the suppletory application of other laws which are inconsistent with the Muslim Code provisions. Thus, the Muslim Code is the primary law that expressly governs all Shari'ah cases, or those that may be reasonably inferred as being within its ambit. Only when the suppletory laws are consistent with the Muslim Code that they have a suppletory application to the latter law. This is undisputed. 
However, Article 187 does allow the suppletory law as a legal basis for the Supreme Court decisions on cases elevated from the Shari'ah courts. It is possible that the suppletory law is given primacy over the primary law. The case of Bondagjy v. Bondagjy presents a situation where the Supreme Court of the Philippines applied the civil law instead of the Muslim Code and the decison seems to exemplify this possibility. This is not entirely good news in the application of the Muslim Code. Parenthetically, Article 187 should not be taken to mean that Muslim personal law is incomplete.The Shari'ah, of which the personal law is part of, is not in need of the suppletory application of other secular laws as it is a complete legal system itself.

Of the foregoing 'safety-net' provisions in the Muslim Code favouring the non-Muslim spouse, it is Article 3(3) which deserves special attention for its profound implications concerning the applicability of the Muslim Code.

\section{Article 3(3) of the Muslim Code}

Article 3(3) may be considered as a two-pronged provision. First, the provisions of the Muslim Code shall be applicable only to Muslims. ${ }^{8}$ Second, nothing in the Muslim Code shall be construed to operate to the prejudice of a non-Muslim. Though Article 3(3) is a short provision but it has far-reaching implications. It serves as an inherent veto against the Muslim Code insofar as its application to the non-Muslim party is concerned. In Rulona-Al Awadhi v. Astih, ${ }^{9}$ the Supreme Court of the Philippines, aside from holding that the Shari'ah District Court did not have jurisdiction because of the mixed marriage therein is not governed by the Muslim Code, whereby the court further held that 'the application of the Muslim Code to the Christian wife will be prejudicial to her.'

\footnotetext{
${ }^{8}$ See Article 7(g), Muslim Code, wherein the word "Muslim" is defined as a person who testifies to the oneness of God and the Prophethood of Muhammad and professes Islam.

${ }^{9}$ Jocelyn Rulona-Al Awadhi v. Hon. Abdulmajid J. Astih, District Judge of the Fourth Sharia Judicial District Court and Nabil Al-Awadhi G.R. No. 81969, September 26, 1988.
} 


\section{Exceptions to the first clause of Article 3(3)}

On the face of it, the provision of Article 3(3) seems to be absolute, as it is not subjected to any condition whatsoever. However, a thorough assessment of this provision reveals that its first clause is not absolute. There are instances where the Muslim Code provisions apply to nonMuslims. In Villagracia v. Fifth $\left(5^{\text {th }}\right)$ Shari'a District Court, ${ }^{10}$ the Supreme Court of the Philippines made mention of these instances as follows:

"True, no provision in the Code of Muslim Personal Laws of the Philippines expressly prohibits non-Muslims from participating in Shari' a court proceedings. In fact, there are instances when provisions in the Muslim Code apply to non-Muslims. Under Article 13 of the Muslim Code, provisions of the Code on marriage and divorce apply to the female party in a marriage solemnized according to Muslim law, even if the female is non- Muslim. Under Article 93, paragraph (c) of the Muslim Code, a person of a different religion is disqualified from inheriting from a Muslim decedent. However, by operation of law and regardless of Muslim law to the contrary, the decedent's parent or spouse who is a non-Muslim "shall be entitled to one-third of what he or she would have received without such disqualification." In these instances, non-Muslims may participate in Shari'a court proceedings."

This pronouncement is a concession that the first clause of Article 3(3) is not absolute. As clearly indicated, the Muslim Code provisions apply to non-Muslims in specific instances under Article 13 and Article 93(c). However, the author believes that these are not the only instances under the Muslim Code where the provisions thereof apply to nonMuslims. For instance, Article 179 of the Muslim Code ${ }^{11}$ provides that the obligation of or liability incurred by a Muslim is not extinguished by his or her subsequent change of religion. Thus, his obligation or liability

${ }^{10}$ Vivencio B. Villagracia v. Fifth $\left(5^{\text {th }}\right)$ Shari'a District Court and Roldan E. Mala, represented by his father Hadji Kalam T. Mala G.R. No. 188832, April 23, 2014. [Boldfacing supplied]

${ }^{11}$ Article 179. Effect of change of religion. The change of religion by a Muslim shall not have the effect of extinguishing any obligation or liability whatsoever incurred prior to said change. 
incurred under the Muslim Code continues to be effective even if he or she is now a non-Muslim. ${ }^{12}$ Under Article 181 of the Muslim Code, ${ }^{13}$ a non-Muslim who solemnizes any marriage purportedly under the Muslim Code is considered as an illegal solemnization of marriage with the penalty of imprisonment or a fine or both. Under Article 182 of the Muslim Code, ${ }^{14}$ any widow or divorced woman, whether Muslim or not, shall suffer the penalty of a fine not exceeding five hundred pesos if she contracts another marriage before the expiration of the prescribed 'iddah. ${ }^{15}$

The existence of these exceptions to Article 3(3) seems to suggest that Article 3(3) is not an absolute provision. Hence, the present author believes that the Muslim Code should not be straightjacketed by a strict interpretation of Article 3(3) when the Muslim Code's applicability is found to exist like in the case of Bondagjy v. Bondagjy.

\section{APPLICATION OF ARTICLE 3(3) IN RELATION TO THE REQUIREMENT OF GOOD FAITH AND HONESTY, AND THE RELEVANT IMPLICATIONS OF BONDAGJY v. BONDAGJY}

The second clause of Article 3(3) provides that "nothing herein shall be construed to operate to the prejudice of a non-Muslim." This provision seems to be clear and unambiguous, thus not requiring construction but

\footnotetext{
${ }^{12}$ For instance, he is obliged to give mahr (customary dower), if owing, even after he becomes non-Muslim after the marriage.

${ }^{13}$ Article 181. Illegal solemnization of marriage. "Any person who shall, without authority, solemnize any marriage purportedly under this Code, or shall do so in a manner contrary to the provisions thereof, shall be punished by imprisonment of not less than two months but not more than two years, or a fine of not less than two hundred pesos but not more than two thousand pesos, or both, in the discretion of the court." [Boldfacing and underscoring supplied] A non-Muslim is clearly without authority to solemnize Muslim marriages.

${ }^{14}$ Article 182. Marriage before expiration of 'iddah. Any widow or divorced woman who, having been married under Muslim law or under this code, contracts another marriage before the expiration of the prescribed 'iddah shall suffer the penalty of a fine not exceeding five hundred pesos.

15 'Iddah is the period of waiting prescribed for a woman whose marriage has been dissolved by death or by divorce the completion of which shall enable her to contract a new marriage. [Article 56, Muslim Code]
} 
application. However, a fair and constructive assessment of this provision suggests that its application should be subject to qualifications. The logic of Article 3(3) is clear. The Muslim Code provisions shall not be construed to operate to the prejudice of a non-Muslim since the Muslim Code is not applicable to non-Muslims in the first place. However, the literal and strict application of this rule might result in injustice against Muslim parties. This stimulates the formulation of alternative parameters proposed for affirmative consideration of a superior non-Shari'ah court in deciding Shari'ah cases appealed to it from the Shari'ah courts.

A conflict of rights certainly can also be evaluated under the lenses of the doctrine of Abuse of Rights. The reason is clear. It is a familiar maxim that he who comes to court must come with clean hands. However, there are litigants who come with bad faith and dishonesty in their pockets. When this happens, the non-Shari'ah court should appreciate this variable in applying the rule that nothing in the Muslim Code shall be construed to operate to the prejudice of a non-Muslim. Article 3(3) cannot be abused because the rights that the Muslim or nonMuslim parties have under the Muslim Code do not operate outside the doctrine of Abuse of Rights. This doctrine is embodied in Article 19 of the New Civil Code of the Philippines (NCC) in conjunction with Articles 20 and 21 thereof. Where rights are involved, the doctrine is unmistakably relevant. In Dart Philippines, Inc. v. Spouses Francisco and Erlinda Calogcog, ${ }^{16}$ the Supreme Court of the Philippines explained that:

" Under Article 19 of the Civil Code, every person must, in the exercise of his rights and in the performance of his duties, act with justice, give everyone his due, and observe honesty and good faith. To find the existence of abuse of right under the said article, the following elements must be present: (1) there is a legal right or duty; (2) which is exercised in bad faith; (3) for the sole intent of prejudicing or injuring another. Accordingly, the exercise of a right shall always be in accordance with the purpose for which it has been established, and must not be excessive or unduly harsh - there must be no intention to injure another. A person will be protected only when he acts in the legitimate exercise of his right, that is, when he acts with prudence and in good faith, not when he acts with negligence or abuse."

16 G.R. No. 149241, August 24, 2009. [Citations omitted] 
According to the Code Commission that drafted the New Civil Code (NCC) of the Philippines,

"A chapter on human relations was formulated to present some basic principles that are to be observed for the rightful relationship between human beings and the stability of the social order. The lawmaker makes it imperative that everyone duly respect the rights of others." 17

Article 19 of the NCC champions the parameters between human relations in Philippines. Thus, following the heart of this rule, both the spouses in a mixed marriage must, in the exercise of their rights and in the performance of their duties, act with justice, give each other their dues, and observe honesty and good faith. True, in a mixed marriage the non-Muslim spouse cannot be prejudiced by a construction of the Muslim Code that operates to that effect. However, the author argues that this rule should not be applied where the non-Muslim spouse is guilty of bad faith or dishonesty. A contrary holding would render Article 3(3) absurd and unjust to the Muslim party, for it would mean that it operates even in violation of the doctrine of Abuse of Rights. In other words, a non-Muslim spouse who comes to court claiming to have been prejudiced by the operation of the Muslim Code provisions must come to court in good faith and honesty. If the non-Muslim party is guilty of bad faith and dishonesty, then the Muslim Code provisions may be so construed even if the construction results in the prejudice of the non-Muslim party.

In Bondagjy v. Bondagjy, ${ }^{18}$ the Supreme Court did not apply the Muslim Code in resolving the issue of the custody of minor children born to a Muslim marriage since the Muslim mother converted back to Catholicism after the marriage was solemnised. According to the Court, she is no longer bound by the moral laws of Islam in the determination of her fitness to be the custodian of her children. Not necessarily accusing the mother in the cited case of bad faith, dishonesty, and injustice, however, for the sake of argument, suppose that the only purpose of a Muslim mother (Muslim convert) in converting back to another religion was precisely to avail of Article 3(3). She would then assert the argument

${ }^{17}$ Edgardo L. Paras, Civil Code of the Philippines Annotated, Volume 1, Persons and Family Relations (Manila: 2002), 122, citing Report of Code Commission, p. 39.

${ }^{18}$ G.R. No. 140817, December 7, 2001. 
that the moral laws of Islam in the determination of one's fitness to be the custodian of her children no longer apply. What then is the rule under the Muslim Code if the conversion of the Muslim spouse to another faith is attended with bad faith or dishonesty? The Muslim Code is silent on this point.

However, this does not mean that the doctrine of Abuse of Rights embedded in Article 19 of the New Civil Code of the Philippines cannot be applied. Whenever a person exercises a right in a manner that contravenes Article 19 of the NCC, a legal wrong is produced for which the said person is responsible to pay indemnity. While the gist of abuse of rights as an actionable wrong is to hold the defendant liable for damages even if the act is not illicit, however, the proposal to import the doctrine of Abuse of Rights in applying Article 3(3) of the Muslim Code is not intended mainly on the indemnification aspect. What the article seeks to highlight is the compelling demand of the doctrine that good faith and honesty should characterize human relations. This includes relations that transpire within the context of marital and family relations that the Muslim Code governs.

Elaborating on bad faith and good faith in relation to Article 19 of the NCC, the Court further explained in Dart Philippines, Inc. that:

" Malice or bad faith is at the core of Article 19 of the Civil Code. Good faith refers to the state of mind which is manifested by the acts of the individual concerned. It consists of the intention to abstain from taking an unconscionable and unscrupulous advantage of another. It is presumed. Thus, he who alleges bad faith has the duty to prove the same. Bad faith does not simply connote bad judgment or simple negligence; it involves a dishonest purpose or some moral obloquy and conscious doing of a wrong, a breach of known duty due to some motives or interest or ill will that partakes of the nature of fraud. Malice connotes ill will or spite and speaks not in response to duty. It implies an intention to do ulterior and unjustifiable harm. Malice is bad faith or bad motive."19

Thus, we need not belabour on proving the applicability of the doctrine of Abuse of Rights in resolving conflicts of rights under the Muslim Code. That 'malice or bad faith is at the core of Article 19 of the Civil Code' is all it takes to support the application of Article 3(3) of the

${ }^{19}$ Dart Philippines, Inc. v. Spouses Francisco and Erlinda Calogcog, supra. 
Muslim Code in conjunction with the doctrine of Abuse of Rights. The late Justice Paras of the Supreme Court of the Philippines observed with accuracy, "rights must never be abused; the moment they are abused, they ceased to be rights." 20

Accordingly, it is proposed that any non-Muslim, who claims to have been prejudiced because of the construction of any provision of the Muslim Code, must have acted with justice and observed honesty and good faith. Otherwise, the Muslim Code shall be applied even if it will operate to the prejudice of the non-Muslim. The assertion is clear in that every person, be he/she a Muslim or non-Muslim, must act with justice, give everyone his due, and observe honesty and good faith in the exercise of his rights and in the performance of his duties. Hence, a non-Muslim who is guilty of abuse of right should not be allowed to 'straightjacket' the Muslim Code by benefiting from the provision of Article 3(3) of the Muslim Code that nothing in it shall be construed to operate to the prejudice of a non-Muslim.

While Article 3(3) is not the subject matter of Bondagjy v. Bondagjy, however, its implications can be used to emphasize the necessity of applying Article 3(3) together with the requisite good faith and honesty on the part of each party. In Bondagjy, the Court ruled that the mother is no longer bound by the moral laws of Islam on the matter of her fitness to be the custodian of her minor children because she is no longer a Muslim. However, what has been overlooked is that her conversion to Catholicism did not automatically include the conversion of the minor children to Catholicism as well. This means that the minor children continued to be Muslims. "In a very suggestive statement," writes Hammudah Abdalati, "the Prophet declared that every child is born into the true malleable nature of fitrah (i.e., the pure natural state of Islam), their parents later on make them into a Jew, Christian or pagan." ${ }^{21}$

In Islam, every child is born a Muslim without need of baptism from the 'church' and they continue to be considered Muslims until they develop a non-Islamic religious consciousness about God because of their exposure to non-Muslim familial environment. This becomes an even stronger norm if the parents of these children were Muslims before one of

${ }^{20}$ Paras, Civil Code of the Philippines Annotated, 123.

${ }^{21}$ Hammudah Abdalati, Islam in Focus (Damascus: 1977), 119. 
them, the mother for instance, later converts to another religion. However, what the mother did in Bondagjy v. Bondagjy was to unilaterally have the minor children baptized as Christians on December 15, 1996 without the permission of their Muslim father. ${ }^{22}$ This event came prior to the decision of the case was delivered on December 7, 2001. Thus, by the Muslim Code, she was not yet the parent solely vested with parental authority over the minor children because under the said Code, the father and the mother shall jointly exercise parental authority. Consequently, the Bondagjy mother should have at least secured the advice if not the consent of the Muslim father when she interfered with the religious affiliation of their Muslim minor children by having them converted to another religion.

Under Article 71(1), in case of conflict between the father and the mother as to the parental authority over minor children, the father's authority shall prevail "unless there is a judicial order to the contrary." 23 Taking cue from this provision, there was no judicial order denying the Bondagjy father his right to exercise parental authority when the mother had their Muslim minor children baptized as Christians on December 15, 1996. With due respect, it seems to appear that what the Bondagjy mother has done in relation to the religious affiliation of the minor children could probably amount to bad faith and dishonesty. The conversion of a Muslim female (convert) to another religion is one thing and is an exercise of freedom of religion. However, unilaterally causing the conversion of her Muslim minor children to another religion without the advice or permission of their Muslim father is another thing. This probably amounts to bad faith and dishonesty not only to the Muslim father but also to the Muslim minor children who might have been clueless of the implications of the act imposed on them.

${ }^{22}$ In Bondagjy v. Bondagjy, supra, the Supreme Court of the Philippines narrated that: "On December 15, 1996, Sabrina had the children baptized as Christians and their names changed from Abdulaziz Bondagjy to Azziz Santiago Artadi and from Amouaje Bondagjy to Amouage Selina Artadi."

${ }^{23}$ Article 71. Who exercises. (1) The father and the mother shall jointly exercise just and reasonable parental authority and fulfill their responsibility over their legitimate and acknowledged children. In case of disagreement, the father's decision shall prevail unless there is a judicial order to the contrary. 
The significance of applying Article 3(3) together with the requirement of good faith and honesty could not be any clearer. Hence, the author is recommending that the incorporation of the concept of good faith and honesty to the provision of Article 3(3) must be made categorical. There are two (2) ways by which it can be done. First is by the legislative method of incorporating an amendment adding a provision subjecting the application of Article 3(3) to the requirement of good faith and honesty, though this may not be necessary considering the suppletory applicability of Article 19 of the New Civil Code.

Second is by the judicial method of reading into Article 3(3) the requisite good faith and honesty on the part of each party to a Shari'ah case, Muslim and non-Muslim alike.

\section{IMPLICATIONS OF BONDAGJY v. BONDAGJY ON THE APPLICABILITY CLAUSE (ARTICLE 13) AND CONFLICT OF PROVISIONS (ARTICLE 3) OF THE MUSLIM CODE}

The question posed in the case of Bondagjy v. Bondagjy was:

"Is a wife, a Christian who converted to Islam before her marriage to a Muslim and converted back to Catholicism upon their separation, still bound by the moral laws of Islam in the determination of her fitness to be the custodian of her children?

We apply the civil law in the best interest of the children."24

With due respect to the Supreme Court of the Philippines, Bondagjy v. Bondagjy sidestepped the clear applicability of the Muslim Code. The Bondagjy Muslim marriage was solemnized in accordance with Islamic rites at the Manila Hotel, Ermita, Manila. Therefore, the Muslim Code applies for Article 13(1) provides that the provisions of the title on marriage and divorce shall apply to marriage and divorce wherein both parties are Muslims, or wherein only the male party is a Muslim and the marriage is solemnized in accordance with Muslim law or the Muslim Code in any part of the Philippines. In this case, BOTH the parties were Muslims at the time the marriage was solemnised. Therefore, the Code is clearly applicable to them.

${ }^{24}$ Bondagjy v. Bondagjy, supra. 
The next issue then is on the other matters related to the marriage governed by the Muslim Code. Article 13(3) enumerates these matters, which include among others guardianship and custody of minors. These matters 'shall be governed by this [Muslim] Code and other applicable Muslim laws. ${ }^{25}$ To contextualize, since the Muslim Code governs the Bondagjy marriage, then it follows that the Muslim Code and other applicable Muslim laws shall likewise govern the related matter of custody of their minor children pursuant to the clear language of Article 13(3). What seemed to have cancelled the applicability of the Muslim Code in the said case was the fact that the female spouse, previously a Muslim convert, converted back to Catholicism. Alas, the Supreme Court of the Philippines in Bondagjy declared:

"The standard in the determination of sufficiency of proof, however, is not restricted to Muslim laws. The Family Code shall be taken into consideration in deciding whether a non-Muslim woman is incompetent. What determines her capacity is the standard laid down by the Family Code now that she is not a Muslim."

Should a similar case arise in the future, Bondagjy implies that the Muslim wife may simply convert out of Islam to avoid the applicability of the Muslim Code. Bondagjy therefore is inadvertently suggestive of a possible legal strategy - how to avoid the applicability of the Muslim Code on the issue of custody of minor children - that is completely at the option of the Muslim wife.

Though Bondagjy dealt with a specific issue, yet the case is capable of repetition. Where minor children are involved, the issue of custody may be reasonably expected to arise in marital conflicts. Thus, it is proposed with due respect that the conversion of the Muslim wife to another religion should not render the Muslim Code inapplicable in the matters enumerated in Article 13(3) thereof. There are formidable reasons to support this hypothesis. First, the conversion of the Muslim wife to another religion is not a ground for automatic dissolution of the Muslim marriage to take it out from the coverage of the Muslim Code. Hence, notwithstanding the conversion of the Muslim wife to another religion, the Muslim Code still applies, not the Family Code of the Philippines or the civil law. Second, under Article 13 of the Muslim Code as a whole, even if the female party is a non-Muslim, her Muslim

${ }^{25}$ See Article 13(3), Muslim Code. 
marriage and 'the essential requisites and legal impediments to marriage, divorce, paternity and filiation, guardianship and custody of minors, support and maintenance, claims for customary dower (mahr), betrothal, breach of contract to marry, solemnization and registration of marriage and divorce, rights and obligations between husband and wife parental authority, and the properly relations between husband and wife shall be governed by [the Muslim] Code and other applicable Muslim laws. ${ }^{26}$ Stated more categorically, the conversion of the Muslim female to another religion does not operate as an amendment to Article 13 as a whole. Neither can it be so judicially construed in that way for it may amount, with due respect, to judicial legislation. The only effect that the Muslim wife's conversion to another religion has, is to make the marriage mixed, during the subsistence of which the Muslim Code continues to apply under Article 13.

\section{Reconciling Article 3(3) and Article 13 of the Muslim Code}

True, Article 3(3) provides that the Muslim Code provisions are applicable only to Muslims. However, Article 13(1) also provides that the provisions on marriage and divorce including those matters covered by Article 13(3) shall apply to marriage and divorce "wherein both parties are Muslims,' 'or wherein only the male party is a Muslim and the marriage is solemnized in accordance with Muslim law or this Code in any part of the Philippines.' Initially, there seems to be a conflict between the two provisions, though the same is not irreconcilable. Article 3 deals with conflict of provisions under the title on Construction of Code and Definition of Terms.

It is a provision of the rules on resolving conflict of provisions in general. Paragraph 3 thereof provides that the Muslim Code provisions are applicable only to Muslims. Since the parties in the Bondagjy trial were both Muslims, at the time of the solemnization of the marriage, it is at this point that the determination of the applicability of the Muslim Code is to be determined. Its import is that the Muslim Code does not apply to the non-Muslim party, if the marriage was solemnised under the civil code. On the other hand, Article 13 of the Muslim Code deals with the Muslim Code applicability on marriage and divorce and those matters

${ }^{26}$ See Article 13(3), Muslim Code. 
covered by paragraph 3 thereof. Article 13 therefore deals with a more specific subject, i.e., the applicability of the Muslim Code on marriage, divorce, and related matters.

The foregoing necessitates an illustration. A non-Muslim male cannot marry more than four wives at a time even if he invokes the Muslim Code that allows it because he is not a Muslim. Article 3(3) bars him from availing of this option since the Muslim Code provisions pertinent thereto are applicable only to Muslims. Likewise, he cannot divorce his wife through talaq under the Muslim Code because the latter law does not apply to him for being a non-Muslim. In the same vein, a non-Muslim female cannot claim customary dower (mahr) from her nonMuslim husband even if she invokes the Muslim Code that requires it as the husband's obligation because the pertinent provisions on mahr do not apply to them for being non-Muslims. These pertinent Muslim Code provisions do not apply to their person as non-Muslims. This is the gist of Article 3, particularly paragraph 3 thereof. To clarify further, we need to frame questions properly. Does the Muslim Code apply to non-Muslims in general? Article 3(3) supplies the answer to this general question in the negative. Does the Muslim Code apply to marriage wherein both parties are Muslims or wherein only the male party is a Muslim, the female party being a non-Muslim? Article 13 deals with this specific question about the Muslim Code applicability to marriage.

However, suppose that Article 3(3) and Article 13 of the Muslim Code cannot be reconciled. How may the conflict of these provisions be resolved? This requires a determination of the nature of the two provisions. Article 3(3) of the Muslim Code is a general provision that deals with the non-applicability of the Muslim Code provisions to nonMuslims in general, whereas, Article 13 thereof is a specific provision that deals inter alia with the applicability, under certain conditions, of the Muslim Code provisions on marriage wherein both parties are Muslims or wherein only the male party is a Muslim, the female party being a nonMuslim. The pertinent rule in statutory construction demands that the two provisions of the same statute be reconciled first. In case the conflicting provisions cannot be reconciled, then the specific provision prevails over the general provision.

In sum, the Muslim wife's conversion to another religion does not, and should not, paralyze the Muslim Code applicability to the Muslim marriage referred to in Article 13(1) and to related matters enumerated in 
Article 13(3) thereof. Ergo, the pertinent Muslim Code provisions and other applicable Muslim laws, not the Family Code of the Philippines, should have been applied in resolving the issue of custody of minor children in Bondagjy v. Bondagjy despite the conversion of the Muslim wife to Catholicism, with due respect to the Supreme Court of the Philippines.

\section{Conflict of provisions between the Muslim Code and Civil Law}

Nowhere in Bondagjy v. Bondagjy was it mentioned that it involved a conflict of provisions between the Muslim Code and civil law, particularly the Family Code of the Philippines. In fact, the Bondagjy decision seems to suggest that there is no conflict of provisions between the two laws. For instance, on the issue of fitness of a mother, the Bondagjy ruling says:

" The burden is upon respondent to prove that petitioner is not worthy to have custody of her children. We find that the evidence presented by the respondent was not sufficient to establish her unfitness according to Muslim law or the Family Code."27

Stripped of its fundament, Bondagjy revolved around the question of the fitness of the mother in relation to the custody of the minor children. In this respect, the Muslim law and the civil law or family law of the Philippines differ on the issue of fitness of a mother. The Shari'ah District Court, deciding based on the Muslim Code, held that the Bondagjy mother was unfit to care for her minor children. It held:

"xxx Under the general principles of Muslim law, the Muslim mother may be legally disentitled to the custody of her minor children by reason of 'wickedness' when such wickedness is injurious to the mind of the child, such as when she engages in 'zina' (illicit sexual relation); or when she is unworthy as a mother; and, a woman is not worthy to be trusted with the custody of the child who is continually going out and leaving the child hungry. (A. Baillie, Muhammadan Law, p. 435; citing Dar-ul-Muktar, p. 280)."28

${ }^{27}$ Bondagjy v. Bondagjy, supra.

${ }^{28} \mathrm{Id}$. 
The pronouncement of the court a quo in Bondagjy appears to be congruent with the qualifications, among others, of female custodian or guardian under Muslim law that she can be trusted with the minor in the sense that she is not always going out of her house; she must not be an apostate; she should not keep the ward in a place where he or she shall be staying with a person who is not related to him or her within the prohibited degrees in marriage; she can tackle the affairs of the guardianship; she must not be married to a husband who is not related to the ward within the prohibited degrees in marriage. ${ }^{29}$

However, the Supreme Court did not see it in a similar way, for it was using the lenses of civil law. Clearly, there was a conflict between the Muslim Code and other applicable Muslim laws on the one hand and the civil law or the Family Code of the Philippines on the other hand on the issue of fitness of the mother to have custody of the minor children in Bondagjy. Therefore, considering that Bondagjy involved a conflict between the two laws, then the conflict of provisions rules found in Article 3 of the Muslim Code must be applied because the latter law supposedly governs the Bondagjy Muslim marriage. Article 3(1) provides that in case of conflict between any provision of this [Muslim] Code and laws of general application, the former shall prevail. Hence, by clear language of Article 3(1), the Muslim Code shall prevail in case of conflict between any of its provisions and the civil law or the Family Code of the Philippines, the latter laws being laws of general application.

\section{IMPLICATIONS OF BONDAGJY v. BONDAGJY ON THE MUSLIM CODE - PERTINENT PROVISIONS ON CUSTODY AND PARENTAL AUTHORITY}

The price of not applying the Muslim Code in a Shari'ah case may not be immediately apparent because it is just typical of winner-loser culmination of the litigation process. Like in civil courts, litigations involving Shari'ah cases must likewise come to an end for the winning parties to enjoy the fruits of their court victory. Sooner or later, the losing party will accept this reality. Initially, Bondagjy may not be that different. In the Bondagjy litigation, the ultimate victor was the mother. However, the grant of custody in favor of the Bondagjy mother has profound

${ }^{29}$ Alauya, Quizzer, 92. 
implications on the so-called 'best interest' of the minor children. This makes Bondagjy not just an ordinary winner-loser culmination of a court litigation. In fact, it was just the continuation of reality outside pleadings and other court documents, not only on the part of the mother but more significantly on the part of the minor children as well.

We concede that the following Bondagjy pronouncement is true:

"Indeed, what determines the fitness of any parent is the ability to see to the physical, educational, social and moral welfare of the children, and the ability to give them a healthy environment as well as physical and financial support taking into consideration the respective resources and social and moral situations of the parents." 30

"Under the Shari'ah," writes Prof. Dr. Hamid A. Barra, "the cardinal concern related to custody is the welfare of the child and the promotion of its well-being." ${ }^{11} \mathrm{He}$ explained that the jurists agreed on this and that they disagreed only on "until what time may the mother be fit to take care and exercise custody over the child seven years of age, puberty, marriage." "However, these difference all focus to one objective, and that is the well-being of the child," he clarified citing $H$. Abd al-Ati. Moreover, in his reading of the following Malaysian cases decided by the Shari'ah courts of Kelantan, namely: Wan Abdul Aziz v. Siti Aishah $(1975)^{33}$, Wan Khadijan v. Ismail (1975) ${ }^{34}$, and Ahmad v. Aishah $(1975)^{35}$, Prof. Dr. Barra concluded:

"...that the courts have always considered the welfare and well-being of the child, that the rights of the child to a decent life, moral and religious upbringing, early education and training and the like, must always be upheld and eyed with respect. It cannot be denied that the early formative years of the child are the most important ones in his development as a

\footnotetext{
${ }^{30}$ Bondagjy v. Bondagjy, supra.

${ }^{31}$ Hamid Aminoddin Barra, The Code of Muslim Personal Laws: A Study of Islamic Law in the Philippines (Marawi City: MSU College of Law, King Faisal Center for Islamic, Arabic, and Asian Studies, 1988), 128.

${ }^{32} \mathrm{Id}$.

${ }^{33} 1 \mathrm{JH}(1)$ 53; (1980) Survey 347.

${ }^{34} 1 \mathrm{JH}(1)$ 53; (1980) Survey 347.

${ }^{35} 1 \mathrm{JH}(1) 55$; (1980) Survey 348.
} 
human being. Thus, care must be exercised in choosing the right person to have his custody." 36

Taking cue from this authoritative observation, the present author is ready to assert that the most important factor in the rearing of Muslim children is to attune custody and parental authority over the children to the true teachings and demands of Islam. As succinctly observed by Abdalati, "...Islam is strongly sensitive to the crucial dependence of the child on the parents. Their decisive role in forming the child's personality is clearly recognized in Islam. "37

The Islamic perspective on custody and parental authority is articulated in the Muslim Code, which includes applicable Muslim laws on these family matters. In other words, the determination of the best interest of the Bondagjy minor children should have been made in accordance with the Muslim Code. This is because they were Muslims born to an initially Muslim couple, in a Muslim marriage to which the Muslim Code applies. That the Muslim wife later converted to another religion did not affect the status of the minor children as Muslims. They continued to be Muslims. To reiterate, in Islam, every child is born a Muslim without need of baptism from any 'church' and they continue to be considered Muslims until they develop a non-Islamic religious consciousness about God because of their exposure to non-Muslim familial environment. This becomes more immutable if the parents of the children were originally Muslims. However, in Bondagjy, what the mother did was to unilaterally have the minor children baptized to Christianity without the permission of their Muslim father. When this occurred, their best interest as Muslim minor children was seriously affected.

It is not difficult to agree that "[t]he welfare of the minors is the controlling consideration on the issue." 38 Both the Muslim Code and the Family Code of the Philippines are geared towards looking after the welfare of minor children. However, the lenses used by the two laws in viewing the welfare of minor children are different in some ways. For instance, remaining in Islam is an essential element of the welfare of a Muslim from the cradle to the grave, nay, from this world to the next.

\footnotetext{
${ }^{36}$ Barra, The Code of Muslim Personal Laws, 130.

${ }^{37}$ Abdalati, Islam in Focus, 119.

${ }^{38}$ Ibid.
} 
Thus, under Article 72(1) of the Muslim Code, children shall respect, revere, and obey their parents always unless the latter cast them into disbelief. This provision is demonstrative of the importance of the maintenance of the Islamic faith of Muslim children. The duty of Muslim children in relation to their parents is that they shall respect, revere, and obey them always.

However, when their parents cast them into disbelief, e.g. letting them abandon Islam to convert to another religion, Muslim children are not bound to obey them. It is in the best interest of Muslim children that they remain in the folds of Islam even if the order to convert to another religion comes from their own parents. Having the Muslim minor children baptized to another religion, like what the mother did in Bondagjy, is not promotive of their welfare and best interest as Muslim minor children. This is because what could enhance and protect their welfare and best interest as Muslims is their Islamic upbringing under the care and guidance of their Muslim parents who profess Islam. This assertion finds support in a prophetic hadith concerning a child whose father was a Muslim and whose mother was a non-Muslim. Referring to this hadith, Prof. Dr. Barra elaborated that in this incident,

" The Prophet (s.a.w.) asked the father to stay on one side and the mother on another side. Then he asked them to call the child. At first, the girl went to the mother. But the Prophet prayed that the girl will make a wise choice. So, he asked again the parents to call the girl. This time, she went to the father. Thus, she was given to him. The decision of the Prophet in this case is based on the presumption that because the father was a Muslim, he was in a better position to take care of the girl's well-being and raise her as a Muslim." 39

Every parent and every person exercising parental authority shall see to it that the rights of the children are respected, and their duties complied with, and shall particularly by precept and example, imbue them with religious and civic attachment to the ideal of permanent world peace. ${ }^{40}$ This provides a bird's-eye view of the duty of parents to their children. It is conceded that this duty of parents to their children may be accomplished by said parents regardless of their religion. However, the

39 Barra, The Code of Muslim Personal Laws, 128, citing Al-Taj (A comprehensive collection of the most authentic traditions), Vol. II, p. 325. ${ }^{40}$ Article 73, Muslim Code. 
life of a Muslim is inextricably linked to his religion, i.e., Islam. He must construct his life based on Islamic virtues and cleanse it of everything that Islam considers as evil or vice. The same is true with the construction of marital and family life in Islam. Accordingly, the life of a Muslim child must be constructed based on Islam with the guidance of his Muslim parents. Thus, a Muslim child must be guided on what Hammudah Abdalati writes as 'basic concepts' of Islam such as faith (iman), righteousness (birr), piety (taqwa), prophethood, life, religion, sin, freedom, equality, brotherhood, peace, community, morality, and the universe. ${ }^{41}$

Accordingly, the Muslim child must be prepared by his parents to respond to the pillars of Islam namely, the declaration of the oneness of Allah (s.w.t.) and prophethood of Muhammad (s.a.w.), the five (5) daily obligatory prayers, the giving of zakat (alms), the fasting during the holy month of Ramadhan, and the pilgrimage to Makkah. Further, he must understand through the guidance of his Muslim parents that there are things that Islam prohibits like consumption of pork and intoxicants, and indulging in gambling and interest (riba). These are just some of the Islamic injunctions that a non-Muslim parent cannot effectively administer to a Muslim child. Ergo, it is highly improbable if not impossible that the Bondagjy mother who converted back to Catholicism after leaving the folds of Islam can bring Islamic upbringing to the Muslim minor children. When she had them baptized to Catholicism without the advice of their Muslim father, she has closed the chapter of Islamic upbringing in their personal story. The rest is history when she was awarded the custody of the minor children.

In general, there are two situations contemplated in a ward-guardian relationship under the Muslim Code. The first is guardianship where the guardian is a female relative of the ward, and the second is where said guardian is a male relative of the ward. This classification is relevant in relation to the requirement of unity of religion between the ward and the guardian. Writing on this subject, Jurisconsult Saaduddin A. Alauya (ret.) explained that it is not necessary that the female guardian must have the same religion with the ward unless the difference in religion is

${ }^{41}$ See Hammudah Abdalati, Islam in Focus (Damascus: 1977), 23-52. 
detrimental to the faith of the ward. ${ }^{42} \mathrm{He}$ continued that the unity in religion is not a requirement for guardianship when the guardian is a female relative because the bases of the guardianship thereof is the guardian's compassion, kindness and great concern over the ward's welfare and this cannot be affected by the difference in religion... ${ }^{43} \mathrm{He}$ pointed out however that it will be different if the guardian is a male... because the unity in religion is a requirement for guardianship. ${ }^{44}$ The reason behind it is that the rights of males to the guardianship are based on the right to inheritance. ${ }^{45}$

It appears that the custody of the minor children in Bondagjy falls to the kind of guardianship where the guardian is a female relative. Therefore, unity of religion in their case was not a requirement for the guardianship because the basis thereof is their mother's compassion, kindness, and great concern over the welfare of her minor children. In fact, Bondagjy is similar, albeit not exactly, to Alauya's example of a christian wife who is divorced by her Muslim husband and so she can remain and serve as a guardian of their child who is a Muslim following his father's religion unless the difference in religion is prejudicial to the faith of the ward. ${ }^{46}$

We concede that unity of religion (between the ward and the guardian who is a female relative) is not a requirement in guardianship. However, this is subject to the condition that the faith of the ward is not compromised because of difference of religion with his or her female guardian. Prior to the promulgation of the Bondagjy decision on December 7, 2001, the mother was already taking custody of the minor children several years back. The facts of the Bondagjy case illustrate that the minor children were in the custody of their mother at least sometime in December 1995. On December 15, 1996, she had them baptized as Christians and even changed their Muslim names. The mother, as a custodian, thereby demonstrated effectively that she compromised the faith of the Muslim minor children when she had them baptized as

${ }^{42}$ See Saaduddin A. Alauya, The Quizzer in Muslim Personal Law (Marawi City: 1984), 92.

${ }^{43}$ Ibid.

${ }^{44}$ Ibid.

${ }^{45}$ Ibid.

${ }^{46}$ Ibid. 
Christians even though she knew that they were born Muslims in a marriage governed by the Muslim Code.

Therefore, the rule that the unity of religion (between the ward and the guardian who is a female relative) is not a requirement in guardianship is applicable only if the difference in religion is not detrimental or prejudicial to the faith of the ward. By far, the most detrimental or prejudicial act of a third person affecting a Muslim's faith is the act that takes him or her away from Islam. However, this article never suggests that the well-being of the Bondagjy minor children cannot be established by any environment other than that which a Muslim family may provide. We see and affirm how non-Muslim families can give what is best for their children in the name of promoting their well-being. Yet we do not also see any harm to the notion that Muslim children should be raised by their Muslim families for their well-being in this world and the next.

Thus, considering the foregoing, the author tenders and comments on the following statement of the problem:-

"What law shall be applied to resolve the Shari'ah issue of custody of Muslim minor children born originally to a Muslim couple in a Muslim marriage governed by the Muslim Code based on its clear and unambiguous applicability provisions, to promote their best interest?"

It is strange to say that it is not the Muslim Code.

\section{CONCLUSION}

The variables created from the dynamics of mixed marriages that the Muslim Code governs must not alter its applicability as a binding and effective law on persons and family relations. When so determined as applicable, the Muslim Code should be applied even if the controversy is between a Muslim and his non-Muslim spouse in a mixed marriage. That the Muslim female party to a Muslim marriage has suddenly become a non-Muslim should not immediately result in the non-application of the Muslim Code, especially if the marriage is inceptively within its applicability clause. This perspective is necessary for the Muslim Code to retain its character as a law that is binding on all Shari'ah cases over which it is applicable in the Philippines. 
The requirement of good faith and honesty to each party to a Shari'ah case must be appreciated so that a buffer is created against those who come to courts with bad faith and dishonesty claiming that the construction of the Muslim Code operates to their prejudice purportedly in violation of Article 3(3) thereof that nothing in it shall be construed to operate to the prejudice of a non-Muslim. After all, the requirement of good faith and honesty is prevalent in almost all cases involving conflicts of rights where one who abuses his rights through malice or bad faith is made to suffer responsibility for his abuse or wrongdoing. Thus, even in cases within the Muslim Code context, the concept of good faith and honesty assumes an indispensable role for a fair and just resolution of said cases. There is therefore a need to incorporate the concept of good faith and honesty in the application of Article 3(3) of the Muslim Code. This can be done through either the legislative or the judicial method as proposed in this article.

Finally, the resolution of conflicts of rights under the Muslim Code is not simply an adjudication of various opposing pleadings and evidence. It involves more than that. It involves real life stories that sometimes will have to be lived by persons who are not even parties to the case but they must, for it is what the court has decreed pertaining to issues affecting them, e.g. the minor children in Bondagjy v. Bondagjy. The success in Muslim law application over Shari'ah cases arising from mixed marriages, or the implication of Muslim law non-application on these cases, is the paradigm to begin with in all efforts designed to promote mixed marriage as a healthy and significant avenue for Muslim and non-Muslim relations in the Philippines and other foreign jurisdictions where similar relations exist. 